\title{
MENINGKATKAN HASIL PENELITIAN PASSING BAWAH BOLAVOLI DENGAN MODIFIKASI BOLA \\ (Penelitian Tindakan Kelas V SDN Palasari)
}

\author{
Dwi Yulia Nur Mulyadi
}

\author{
Universitas Siliwangi \\ dwiyulianm@yahoo.com
}

\begin{abstract}
Abstrak
Penelitian ini bertujuan untuk mengetahui dapat atau tidaknya modifikasi bola meningkatkan kemampuan mempraktikkan teknik passing bawah bola voli. Metode penelitian yang digunakan adalah metode penelitian tindakan dengan desain Kemmisd dan Mc. Taggart meliputi empat tahap yaitu perencanaan, tindakan, pengamatan, dan refleksi. Yang terdiri dari beberapa siklus dengan prosedur ini jika siklus kesatu tidak mencapai target sebesar 80\%, maka dilakukan siklus kedua dan seterusnya hingga tercapai $80 \%$.

Hasil tes yang diperoleh pada saat observasi awal tidak ada satu pun siswa yang mencapai nilai KKM. Skor terendah 25 dan skor tertinggi 50. Selanjutnya pada siklus ke I terdapat peningkatan kemampuan mempraktikkan teknik dasar passing bawah dengan skor terendah 58,3 dan skor tertinggi 83,3. Pada siklus ke satu terdapat peningkatan sebanyak 10 orang (48\%) yang mencapai KKM. Kemudian pada siklus II tingkat kelulusan siswa meningkat dengan nilai terendah 66,7 dan nilai tertinggi 83,3. Yang berhasil mencapai KKM pada siklus ke II sebanyak 19 orang $(90,48 \%)$.

Karena pada siklus II target keberhasilan telah tercapai maka peneliti tidak melanjutkan penelitian pada siklus berikutnya. Dengan demikian dapat disimpulkan bahwa pembelajaran dengan menggunakan Modifikasi Bola dapat meningkatkan keterampilan mempraktikkan teknik dasar passing bawah bola voli pada siswa kelas V SDN Palasari.
\end{abstract}

Kata Kunci: Passing Bawah, Bola Voli, Modifikasi Bola

\begin{abstract}
The aim of this research is to find out wether or not the modification of the ball improve practice the technique of forearm the volleyball. Method of this research is action research method to design kemmis and mc. Taggart include four stage: planning, action, observastion and reflection. With the consist of several cycle. If the first cycle doesnt reach the target of $80 \%$, then do the second cycle and so on until reach $80 \%$.

The result of the first observation is no one of the student can reach the KKM. The lowest score is 25 and the higest score is 50. At the first cycle there are increased ability to practice the basic technique of forearm pass. With the lower score 58,3 and the higest score is 83,3. At the first cycle there are 10 student (48\%) who got increasing score that reach KKM. Then at the second cycle rate of pass student increased with the lower score 66,7 and the higest score 8,3. Who reached KKM at the second cycle were 19 student $(90,48)$.
\end{abstract}

Because of the second cycle has been reached, so the writer didn't continue to the next cycle. So can be conclude that learning by using the modified ball can increase the skill of practicing basic tehnique of forearm pass volleyball at the fifth grade student of SDN Palasari.

\section{Key Word : Forearm Pass, Volleyball, Modified Ball}

Dipublikasikan Oleh :

UPT Publikasi dan Pengelolaan Jurnal

Universitas Islam Kalimantan Muhammad Arsyad Al-Banjari Banjarmasin 


\section{PENDAHULUAN}

Pendidikan Jasmani, Olahraga, dan Kesehatan (Penjaskes) di sekolah dasar berorientasi pada tujuan pendidikan nasional berdasarkan Kurikulum tahun 2006 yang dikenal dengan istilah Kurikulum Tingkat Satuan Pendidikan (KTSP). Tujuan tersebut dijabarkan menjadi standar kompetensi dan kompetensi dasar untuk setiap semester pada setiap jenjang kelas. Standar kompetensi merupakan kualitas kemampuan minimal peserta didik. Oleh karena itu, standar kompetensi dijabarkan menjadi beberapa kompetensi dasar, dan kompetensi dasar dijabarkan lagi menjadi beberapa indikator.

Salah satu standar kompetensi mata pelajaran Pendidikan Jasmani, Olahraga, dan Kesehatan untuk kelas V semester 1 Sekolah Dasar berdasarkan Kurikulum Tingkat Satuan Pendidikan adalah "Mempraktikkan berbagai variasi gerak dasar ke dalam permainan dan olahraga dengan permainan yang dimodifikasi serta nilai-nilai yang terkandung di dalamnya". Salah satu kompetensi dasar sebagai penjabaran dari standar kompetensi tersebut di atas adalah kompetensi dasar 1. 2 yang berisi, "Mempraktikkan variasi gerak dasar ke dalam modifikasi permainan bola besar, serta nilai-nilai kerjasama, sportivitas, dan kejujuran". Kompetensi dasar tersebut di atas merupakan kompetensi yang harus dimiliki dan dikuasai siswa kelas V sekolah dasar semester 1, namun kenyataan di sekolah masih banyak siswa kelas $\mathrm{V}$ yang belum mampu mempraktikkan teknik dasar passing bawah bola voli.

Sebagai upaya memperbaiki proses pembelajaran dan meningkatkan hasil belajar memperaktikkan passing bawah bola voli siswa kelas V sekolah dasar, penulis melakukan penelitian tindakan. Terdapat beberapa model tindakan atau jenis penelitian tindakan yang dikembangkan oleh para ahli, antara lain model Kurt Lewin, Model John Elliot, Model Kemmis dan Taggart, Model Dave Ebbut, Model McKernan, Model Richard Sagor, Model Emily Calhoun, Model McKernan, Model Richard Sagor Model Richard Sagor, Model Emily Calhoun, Model Lorenz Bachman, dan Model Ernest Stingerm model penelitioan tindakan yang penulis terapkan dalam penelitian ini hanya model Kemmis dan Taggart.

Menurut Kemmis dan Taggart (2014: 18) "We described the spiral of self-reflection in terms of a spiral of self-reflective cycles of: (1) planning a change; (2) acting and observing the process and consequences of the change; (3) reflecting on these processes and consequences, and then (4) re-planning, (5) acting and observing, (6) reflecting,

Pendapat Kemmis dan Taggart di atas memberikan bahwa refleksi diri dalam siklus spiral ini adalah (1) merencanakan perubahan; (2) bertindak dan mengamati proses dan konsekuensi dari perubahan; (3) merefleksikan proses dan konsekuensi; (4) merencanakan kembali; (5) bertindak dan observasi kembali; (6) merefleksikan.

Menurut pandangan beberapa ahli, penelitian tindakan memiliki ciri (1) penelitian tindakan pada dasarnya bersifat reflektif, (2) dilakukan oleh pelaku tindakan, (3) dilakukan untuk meningkatkan kualitas pembelajaran, (4) dilaksanakan secara sistematis, (5) bersifat situasional dan kontekstual, (6) dilakukan untuk memecahkan masalah, (7) mengkaji langkah peme- cahan masalah itu sendiri, dan (8) memperbaiki proses pembelajaran secara berulang atau bersiklus. Oleh karena itu, penelitian ini lebih memfokuskan pada proses pembelajaran sehingga ruang lingkup penelitian lebih jelas yakni ke arah perbaikan proses pendidikan yang dilaksanakan di sebuah sekolah.

Dalam penelitian tindakan ini penulis melaksanakan pembelajaran mempraktikkan teknik dasar passing bawah bola voli dengan menerapkan pendekatan modifikasi alat (bola). Modifikasi dalam pembelajaran Pendidikan Jasmani (Penjas) adalah suatu pendekatan pembelajaran yang mempertimbangkan tahap-tahap perkembangan dan karakteristik siswa sehingga siswa merasa senang dan gembira serta memiliki motivasi belajar yang tinggi. Modifikasi merupakan sebuah pendekatan dalam pembelajaran pendidikan jasmani yang menekankan pada kesenangan, kecakapan jasmani, dan pengayaan gerak anak. Dengan memiliki motivasi belajar yang tinggi, siswa bisa melaksanakan kegiatan belajar yang optimal. Dengan demikian, modifikasi pembelajaran hendaknya mencerminkan karakteristik program pendidikan jasmani itu sendiri.

Bahagia dan Sufyar Mujianto (2009: 29) mengutip pendapat Lutan mengenai tujuan modifikasi, "Modifikasi dalam mata pelajaran pendidikan jasmani diperlukan dengan tujuan agar : a) Siswa memperoleh kepuasan dalam mengikuti pelajaran, b) Meningkatkan kemungkinan

Dipublikasikan Oleh : 
keberhasilan dalam berpartisipasi, dan c) Siswa dapat melakukan pola gerak secara benar." Berdasar pada pendapat Lutan di atas, Bahagia dan Sufyar Mujianto (2009: 29) mengemukakan bahwa pendekatan modifikasi dapat digunakan sebagai suatu alternatif dalam pembelajaran pendidikan jasmani. Dengan pendekatan ini, siswa akan mengikuti pembelajaran pendidikan jasmani dengan senang dan gembira karena pendekatan ini mempertimbangkan tahap-tahap perkembangan dan karakteristik siswa.

Selanjutnya, Bahagia dan Sufyar Mujianto (2009: 30) mengemukakan bahwa jenis-jenis modifikasi dalam pembelajaran Penjas adalah a) modifikasi tujuan pembelajaran, yakni membagi tujuan pembelajaran ke dalam tiga komponen (perluasan, penghalusan, dan penerapan); b) modifikasi materi pembelajaran, guru dapat memodifikasi materi yang diberikan kepada siswa dengan cara mengurangi atau menambah tingkat kesulitan mengenai materi yang akan diberikan dengan menganalisis tingkat kesulitanya agar siswa dapat denganmudah mempelajari materi yang diberikan; c) modifikasi lingkungan, dengan memodifikasi kondisi lingkungan (peralatan, penataan ruang gerak dalam berlatih, jumlah siswa yang terlibat) guru dapat memberikan materi pembelajaran dengan maksimal untuk mendapat hasil yang lebih optimal.

Dalam penelitian ini, diterapkan pendekatan modifikasi bola karena salah satu penyebab ketidakmampuan siswa mempraktikkan teknik dasar passing bawah bola voli itu adalah siswa merasa takut melakukan perkenaan bola. Mereka takut dengan bola voli yang berukuran standar karena berat dan besar. Dalam hal ini penulis menyiasatinya dengan membuat bola yang berukuran sedikit lebih kecil dan lebih ringan dari bola voli standar. Bagian permukaannya terasa lebih halus dan empuk sehingga saat perkenaanbola siswa tidak merasasakit.

Materi pembelajaran mempraktikkan teknik dasar passing bawah dalam pelaksanaan pembelajaran selama pelaksanaan penelitian ini dikemas dalam berbagai permainan. Hal ini penulis lakukan karena anak usia kelas $\mathrm{V}$ sekolah dasar sedang berada pada masa senang bermain. Belajar mempraktikkan teknik dasar passing bawah bola voli melalui berbagai permainan, membuat siswa tidak cepat jenuh dan bosan. Mereka tidak merasa sedang belajar mempraktikkan teknik dasar passing bawah, walaupun sebenarnya sedang belajar mempraktikkan teknik dasar passing bawah.

Pembelajaran yang dikemas dalam berbagai permainan yang sesuai dengan perkembangan usia siswa itu sendiri akan membuat siswa senang dan gembira melakukan kegiatan belajarnya. Pembelajaran yang menarik, yang menyenangkan, yang menimbulkan rasa senang dan gembira para siswa, akan meningkatkan motivasi belajar siswa.

Kemampuan mempraktikkan teknik dasar passing bawah bola voli merupakan salah satu kemampuan gerak. Kemampuan gerak adalah kemampuan untuk melakukan gerakan secara efesien dan efektif. Keterampilan gerak merupakan perwujudan dari kualitas koordinasi dan kontrol atas bagian-bagian tubuh yang terlibat dalam gerakan. Kemampuan gerak adalah perwujudan gerak yang diwujudkan melalui respon-respon muscular yang diungkapkan ke dalam gerakan tubuh, didasari dengan tingkat penampilan yang baik pada cabang olahraga melalui rangsangan, penglihatan, pendengaran, dan rasa. Keterampilan gerak merupakan perkembangan pengendalian gerakan tubuh melalui kegiatan yang terkoordinir antara susunan saraf, otak, otot, dan spinal cord. Perkembangan keterampilan gerak (motorik) meliputi motorik kasar dan halus. Perkembangan motorik dipengaruhi oleh organ otak.

Keterampilan gerak diperoleh melalui proses belajar yaitu dengan cara memahami gerakan dan melakukan gerakan berulang-ulang yang disertai dengan kesadaran fikir akan benar atau tidaknya gerakan yang telah dilakukan. Untuk mencapai tingkatan keterampilan tertentu, lamanya waktu latihan yang diperlukan oleh setiap individu berbeda-beda. Ada yang hanya memerlukan waktu singkat dan ada yang memerlukan waktu yang cukup lama walaupun prosedur dan intensitas belajarnya sama, hal ini disebabkan karena faktor bakat dari setiap individu berbedabeda, ada yang memiliki bakat olahraga dan ada yang tidak. Individu yang mempunyai bakat olahraga akan mampu menguasai keterampilan gerak dalam waktu yang lebih singkat.

Semua jenis keterampilan gerak dapat dilakukan melalui beberapa tahapan tertentu. Jika dilakukan secara berulang-ulang dan sistematis, maka gerakan tersebut bisa menjadi gerakan yang terjadi secara otomatis. Menurut Fitts and Posner dalam buku Cheryl A. Coker (2004: 114), "Learners pass through three distinct stages: (1) Cogitive stage: Development of basic movement pattern (2) Associative: Refinement of movement pattern (3) Autonomous: Performance of

Dipublikasikan Oleh : 
movement virtually automatic". Artinya, peserta didik melewati tiga tahapan berbeda, yaitu: 1) tahap kognitif, perkembangan pola gerak dasar, 2) assosiatif, perbaikan pola pergerakan, dan 3) Autonomous, pelaksanaan pergerakan otomatis.

Oleh karena itu, kemampuan gerak seseorang dipengaruhi atau didukung oleh perkembangan daya pikirnya, perkembangan fisiknya, dan perkembangan mentalnya. Perkembangan ketiga aspek tersebut selaras dengan perkembangan usianya. Begitu pula kemampuan gerak siswa siswa kelas $\mathrm{V}$ sekolah dasar tentu dipengaruhi oleh ketiga aspek tersebut di atas.

Santrock (2011: 31) mengemukakan pendapatnya mengenai perkembangan fisik anak pada usia 6-12 tahun sebagai berikut.

Middle and late childhood (sometimes called the elementary school years) extendsfrom about 6 to 11 years of age. Children master the fundamental skills of reading, writing,and math, achievement becomes a more central theme, and self-control increases. In this period, children interact more with the wider social world beyond their family.

Pendapat Santrock di atas dapat dimaknai bahwa anak usia tengah dan akhir (kadang disebut tahun sekolah dasar) dimulai sekitar 6 sampai 11 tahun. Anak-anak menguasai keterampilan dasar membaca, menulis dan matematika, prestasi menajadi tema yang lebih utama dan pengendalian diri meningkat. Dalam tahapan ini anak berinteraksi dengan dunia sosial yang lebih luas di luar keluarga mereka.

Mengenai perkembangan fisik anak, Dahlan (2006: 183) mengemukakan pendapatnya sebagai berikut.

Pada usia 6-12 tahun, seiring dengan perkembangan fisiknya yang beranjak matang, perkembangan motoriknya sudah dapat terkoordinasi dengan baik. Setiap gerakannya sudah selaras dengan kebutuhan atau minatnya. Pada masa ini akan ditandai dengan kelebihan gerak atau aktivitas motorik yang lincah. Oleh karena itu usia ini merupakan masa yang ideal untuk belajar keterampilan yang berkaitan dengan motorik. Seperti menulis, menggambar, melukis, mengetik (komputer) berenang, main bola, dan atletik.

Sejalan dengan pendapat Dahlan, Tangkudung dan Wahyuningtyas Puspitorini (2012: 19) mengemukakan pendapatnya sebagai berikut.

Perkembangan fisik di masa kanak-kanak bervariasi. Variasi ini dipengaruhi oleh jenis kelamin, asal etnis, genetika, hormon, gizi, lingkungan, atau penyakit yang diderita. Pada anak-anak usia ini, keadaan tubuhnya meningkat mencapai kekuatan yang maksimal jika menggunakan otot-ototnya, demikian juga kemampuanya dalam belajar keterampilan gerak.

Pada hakikatnya, setiap kegiatan belajar mengajar selalu melibatkan dua pelaku aktif yaitu guru dan siswa. Guru sebagai pengajar merupakan pencipta kondisi belajar siswa yang didesain secara sengaja, sistematis dan berkesinambungan. Sedangkan siswa merupakan subyek pembelajar yang merupakan pihak penikmat kondisi belajar yang diciptakan oleh guru dalam proses pendidikan formal atau pendidikan yang dilembagakan. Dengan demikian jelas bahwa kemampuan gerak siswa akan berkembang jika guru membantunya sesuai dengan perkembangan usianya.

Perkembangan kemampuan gerak yang diharapkam dalam penelitian ini adalah kemampuan siswa mempraktikkan teknik dasar passing bawah bola voli. Ketercapaian kemampuan ini ditentukan pula oleh kreativitas gurunya dalam merencanakan dan melaksanakan pembelajarannya. Misalnya dalam penelitian ini, bola yang disiapkan untuk digunakan dimodifikasi oleh guru dengan tujuan untuk menyiasati atau memperbaiki proses dan hasil belajar mempraktikkan teknik dasar passing bawah bola voli.

Bola voli yang dimodifikasi dalam penelitian ini adalah bola yang sengaja dibuat dengan berat lebih ringan dan berukuran lebih jecil dari bola standar. Permukaan bola dibuat lebih empuk dari bola standar dan tidak sakit jika perkenaan bola. Modifikasi bola ini dilakukan dengan tujuan agar siswa mau berlatih mempraktikkan teknik dasar passing bawah dengan. tidak merasa hawatir tangannya sakit karena bolanya berat dan besar 
Dengan bola yang lebih ringan dan empuk, diharapkan siswa lebih tertarik dan nyaman melakukan kegiatan belajar mempraktikkan teknik dasar passing bawah. Bola yang dimodifikasi dibuat dengan menggunakan alat dan bahan yang mudah ditemukan. Proses pembuatannya cukup mudah dan sederhana. Bahan dasar bola modifikasi ini adalah: (1) Bola karet (bola mainan berkarakter kartun; (2) Spons karet; (3) Lem.

Bola voli modifikasi yang dibuat mempunyai keliling antara $65-67 \mathrm{~cm}$ dan berat lebih kurang 160 gr. Untuk lebih jelasnya di bawah ini penulis gambarkan bola modifikasi yang digunakan dalam pembelajaran mempraktikkan teknik dasar passing bawah bola voli pada Gambar 1 di bawah ini.

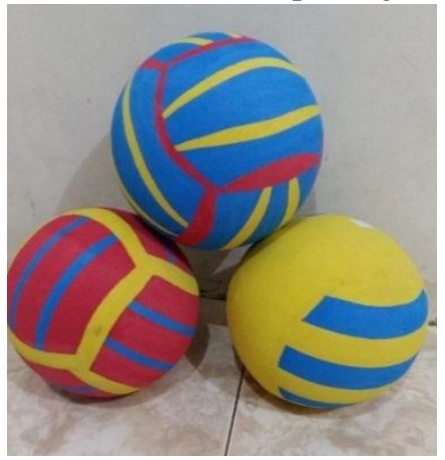

Gambar 1. Bola Modifikasi

Bola voli yang biasa digunakan dalam permainan bola voli adalah bola voli yang sesuai dengan standar internasional yang mempunyai keliking antara $65-67 \mathrm{~cm}$, beratnya antara 250-280 gram, tekanan udara antara $0,48-0,52 \mathrm{~kg} / \mathrm{cm}$.

Permainan bola voli dalam bentuk pertandingan diikuti oleh dua regu yang setiap regu terdiri atas enam orang pemain. Setiap pemain harus memiliki dan menguasai aspek-aspek fisik, teknik, taktik, dan mental untuk memenangkan pertandingan tersebut.

Salah satu aspek yang perlu dikuasai adalah aspek teknik. Menurut Bachtiar (2007: 1.15),

Teknik dapat diartikan sebagai proses kegiatan jasmani atau cara memainkan bola yang ditampilkan dalam bentuk gerakan secara efisien dan efektif untuk mencapai tujuan yang diinginkan serta sesuai dengan peraturan yang berlaku. Teknik yang baik selalu dilandasi oleh teori dan hukum-hukum pengetahuan serta peraturan permainan yang ada.

Menurut Rahmani (2014: 115) "Terdapat beberapa teknik dasar yang dapat dipelajari, di antaranya

servis, passing, smash, dan blocking. setiap teknik dasar tersebut di atas memiliki fungsi yang berbeda. Servis, berfungsi untuk mengawali permainan; Passing, berfungsi untuk menerima/ memainkan bola yang datang dari daerah lawan atau teman seregu; Smash, berfungsi untuk melakukan serangan ke daerah lawan sehingga bola yang akan disebrangkan ke daerah lawan tersebut dapat mematikan minimal menyulitkan lawan dalam memainkan bola dengan sempurna; dan Block atau blok, berfungsi untuk menghadang serangan lawan dari dekat jaring sekaligus sebagai serangan balik ke pihak lawan; dan Receive menjaga bola menyentuh lantai.

Dieter Beutelstahl (2013: 8) menjelaskan bahwa ada enam jenis persentuhan bola, sehingga muncul enam jenis teknik dasar yaitu servis, dig, attack, volley, block, dan defence.

Dig atau passing bawah adalah upaya memberikan bola pada teman seregu untuk dimainkan lagi baik di lapangan sendiri dengan tujuan untuk pertahanan atau untuk penyerangan. Dengan demikian jelas bahwa passing bawah merupakan suatu teknik dasar bola voli yang cukup dominan kepentingannya, karena passing bawah ini berfungsi sebagai dasar untuk mempersiapkan serangan pada pihak lawan dan menjaga bola agar tidak mati di lapangan sendiri.

Viera dan Bonny Jill Ferguson (1996: 115) mengemukakan pendapatnya mengenai lemen dasar untuk pelaksanaan passing bawah yang baik adalah

The basic elements for good execution of the forearm pass are (a) getting to the ball, (b) setting your position, (c) making contact, and (d) following the flight of the ball to the target. When performing the forearm pass, your hands must be joined together: your 
thumbs must be parallel. Your elbows are rotated inward so that the soft, flat portions of your forearms face the ceiling. This platform formed by your arms should be as even as possible. Your arms should be parallel to your thighs; hold them away from your body. You must try to position your body behind the ball, absorb the force, and direct the ball to the target using your body, through leg extension, while contacting the ball with little or no arm swing (poking action).

Elemen dasar untuk pelaksanaan passing bawah yang baik adalah (a) perkenaan pada bola, (b) pengaturan posisi, (c) membuat kontak, dan (d) mengikuti arah laju bola menuju target. Ketika melakukan passing bawah, kedua tangan harus bergabung bersama: dengan ibu jari dirapatkan. Siku diayunkan sehingga lurus ke atas. Lengan harus sejajar dengan paha, dan menahan bola. Memposisikan tubuh di belakang bola, menyerap tenaga, dan mengarahkan bola ke target menggunakan tubuh, melalui ekstensi kaki, sementara saat perkenaan dan mendorong bola, lengan sedikit diayun atau tanpa diayun.

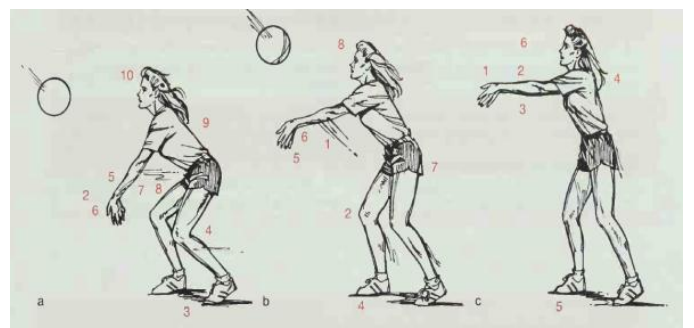

Gambar. 2. Tahapan Gerak Teknik Passing Bawah Bola Voli

(Barbara L. Viera dan Bonny Jill Ferguson. Volleyball Step to Success 1996:15)

Hasil belajar dalam pembelajaran selama penelitian ini adalah perubahan kemampuan siswa kelas $\mathrm{V}$ sekolah dasar mempraktikkan teknik dasar passing bawah, dari tidak mampu menjadi mampu. Hal ini sejalan dengan pengertian belajar. Belajar pada dasarnya adalah perubahan tingkah laku yang relatif menetap akibat adanya interaksi antara individu pembelajar dengan lingkungan sehingga membentuk suatu pengalaman. Pengalaman dapat berupa interaksi dengan lingkungan eksternal dan melibatkan proses yang tidak nampak. Belajar merupakan proses untuk memperoleh prestasi hasil belajar. Belajar merupakan prilaku aktif siswa dalam menghadapi lingkungan untuk mendapatkan pengalaman, pengetahuan, pemahaman, dan makna. Menurut Gagne dalam Ratna Wilis Dahar 2011: 2), "Belajar dapat didefinisikan sebagai suatu proses dimana satu organisasi berubah perilakunya sebagai akibat pengalaman.

Bagi Gagne, belajar dimaknai sebagai suatu proses untuk menghasilkan perubahan dalam pengetahuan, keterampilan kebiasaan dan tingkah laku. Gagne dalam teorinya yang disebut The domains of learning, menyimpulkan bahwa segala sesuatu yang dipelajari oleh manusia dapat dibagi menjadi lima kategori (keterampilan motoris, informasi verbal, kemampuan intelektual, strategi kognitif, dan sikap).

Berdasarkan uraian mengenai belajar di atas, dapat dipahami bahwa belajar yaitu perubahan-perubahan yang terjadi pada diri siswa baik yang menyangkut aspek kognitif, afektif dan psikomotor sebagai hasil dari proses belajar atau hasil belajar. Hasil belajar merupakan tingkat keberhasilan siswa dalam mempelajari suatu materi pelajaran yang dinyatakan dalam bentuk nilai yang diperoleh dari suatu tes di sekolah. Secara sederhana, hasil belajar merupakan kemampuan yang diperoleh anak setelah menjalani proses belajar.

Hasil belajar tersebut selalu dinyatakan dalam bentuk tujuan-tujuan (khusus) perilaku (unjuk kerja). Menurut Susanto (2011: 2), ““‘....makna hasil belajar, yaitu perubahan-perubahan yang terjadi pada diri siswa baik yang menyangkut aspek kognitif, afektif dan psikomotor sebagai hasil dari proses belajar". Hasil belajar merupakan perubahan perilaku berupa pengetahuan, keterampilan, sikap, informasi dan atau strategi kognitif yang baru dan diperoleh siswa setelah berinteraksi dengan lingkungan dalam suatu suasana atau kondisi pembelajaran. Pengetahuan, keterampilan, sikap, informasi atau strategi kognitif tersebut adalah baru, bukan yang telah dimiliki siswa sebelum memasuki kondisi atau situasi pembelajaran dimaksud. Hasil belajar bisa 
juga berbentuk kinerja atau unjuk kerja (performance) yang ditampilkan seseorang setelah selesai mengikuti proses pembelajaran atau pelatihan.

Pengertian hasil belajar erat kaitannya dengan perubahan tingkah laku seseorang setelah dilakukan proses belajar mengajar. Hasil belajar selalu menunjukkan kepada suatu proses perubahan tingkah laku atau pribadi seseorang, dengan berdasarkan pada praktik atau pengalaman tertentu. Perubahan tingkah laku yang dimaksud adalah menyeluruh.

Memahami pengertian hasil belajar di atas, dapat disimpulkan bahwa yang dimaksud hasil belajar adalah hasil yang dicapai seseorang berupa perubahan tingkah laku dalam aspek kognitif, afektif dan psikomotor setelah mengalami situasi belajar. Dengan demikian dapat disimpulkan bahwa hasil belajar merupakan salah satu indikator yang sangat penting dari keseluruhan proses pendidikan umumnya, khususnya proses belajar.

Hasil belajar yang diharapkan dicapai siswa dalam penelitian ini adalah kemampuan memprakrikkan teknik dasar passing bawah bola voli.

\section{METODE}

Metode penelitian yang digunakan dalam penelitian ini adalah metode tindakan, dengan menggunakan desain penelitian model Kemmis dan Mc. Taggart yang berupa siklus atau putaran kegiatan yang meliputi empat tahap diantaranya:

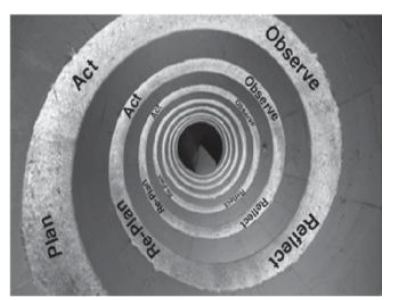

Gambar 3. Model Spiral Kemmis dan taggart

(Stephen Kemmis, Robin McTaggart dan Rhonda Nixon, 2014: 19)

Langkah pertama yang dilakukan dalam penelitian ini adalah perencanaan (planing). Dalam tahap perencanaan ini meliputi observasi awal, melihat kondisi awal pra siklus, mendiskusikan hasil, menentukan materi yang akan diberikan pada saat memulai penelitian. Langkah kedua adalah tindakan dalam tahap pemberian tindakan. Penelitian ini dilaksanakan dalam dua siklus karena pada siklus kesatu baru 10 orang siswa yang berhasil mencapai KKM yang ditentukan sekolah.

Skenario tindakan yang telah direncanakan, dilaksanakan dalam situasi yang aktual. Dalam pel;aksanaan kegiatan ini, juga dilakukan kegiatan observasi dan interprestasi yang dilanjutkan dengan kegiatan refleksi. Pada tahap ini kegiatan belajar yang dilaksanakan mengacu pada perencanaan tindakan yang telah ditetapkan atau melaksanakan pembelajaran sesuai rencana pembelajaran yang telah dibuat. Tahap ketiga yakni pengamatan (observing). Pengamatan dilakukan selama proses pemberian tindakan untuk mengetahui apa saja yang terjadi selama proses pemberian tindakan. Yang keempat adalah refleksi (reflecting) pada tahap ini dilakukan refleksi untuk mengkaji semua data dan catatan lapangan pada saat proses pemberian tindakan dan hasil refleksi tersebut dijadikan acuan pada pemberian tindakan selanjutnya.

Dalam penelitian ini peneliti berperan sebagai guru yang merencanakan dan melaksakan pembelajaran/penelitian tindakan sebagai upaya meminimalkan permasalahan yang dihadapi. Pelaksanaan tindakan ini dilakukan dalam sklus-siklus siklus. Dari setiap siklus diperoleh temuantemuan yang menggambarkan kelebihan dan kekurangan yang dapat dijadikan bahan pertimbangan untuk merencanakan dan melaksanakan tindakan selanjutnya.

Partisipan dalam penelitian ini adalah siswa kelas V SD Negeri Palasari Kota Tasikmalaya tahun ajaran 2015/2016 sebanyak 21 orang (11 orang siswa laki-laki dan 10 orang siswa perempuan). Data yang diperoleh adalah data peoses pembelajaran dan data hasil belajar passing bawah. Data proses belajar diperoleh dari hasil observasi yang dilakukan oleh guru dan 
mitra peneliti sebagai kolaborator. Data hasil belajar diperoleh dari tes yang dilakukan setelah selesai setiap siklus. Data tersebut diambil pada saat pra siklus, siklus I, dan siklus II.

\section{HASIL DAN PEMBAHASAN}

Pada dasarnya pembelajaran melalui pendekatan bola modifikasi cukup memberikan semangat pada siswa dalam mempraktikkan teknik dasar passing bawah bola voli. Siswa lebih antusias dalam mengikuti pembelajaran. Hal ini dapat diamati dari sikap siswa yang awalnya khawatir dalam melakukan passing bawah menggunakan bola yang sebenarnya karena takut sakit, berubah menjadi senang setelah menggunakan bola modifikasi. Siswa yang pada pra penelitian tidak bersungguh-sungguh dan kurang disiplin, berubah menjadi lebih antusias sehingga mereka terlihat bersungguh-sungguh, disiplin, dan lebih aktif. Mereka berani mencoba mempraktikkan teknik dasar passing bawah, tidak terlihat hawatir dan takut sakit ketika mempraktikkan sikap perkenaan bola.

Hasil analisa mengenai hasil pembelajaran pada pertemuan setiap siklus I dan II dapat disimpulkan bahwa terjadi peningkatan hasil belajar passing bawah bola voli pada siswa kelas $\mathrm{V}$ SDN Palasari tahun pelajaran 2015/2016. Dapat dilihat dalam tabel berikut:

Tabel. 4.10 Data Perbandingan Hasil Tindakan Tiap Siklus

\begin{tabular}{|c|c|c|c|c|c|c|c|c|}
\hline \multirow{2}{*}{ NO } & \multirow{2}{*}{ Nilai } & \multicolumn{2}{|c|}{ Pra SIklus } & \multicolumn{2}{c|}{ Siklus I } & \multicolumn{2}{c|}{ Siklus II } & \multirow{2}{*}{ Ket } \\
\cline { 3 - 8 } & & $\mathrm{F}$ & $\%$ & $\mathrm{~F}$ & $\%$ & $\mathrm{~F}$ & $\%$ & \multirow{2}{*}{ Belum Lulus } \\
\hline 1 & $<70$ & 21 & 100 & 11 & 52 & 2 & 9,48 & Lulus \\
\hline 2 & $>70$ & 0 & 0 & 10 & 48 & 19 & 90,52 & \multicolumn{2}{c}{} \\
\hline \multicolumn{2}{r}{ Jumlah } & 21 & 100 & 21 & 100 & 21 & 100 & \multicolumn{2}{c}{} \\
\hline
\end{tabular}

Data di atas menunjukkan bahwa data awal tidak ada siswa yang lulus dari jumlah keseluruhan siswa. Kemudian pada siklus I siswa yang lulus atau sudah memenuhi KKM sebanyak 10 orang atau sebesar $48 \%$ dari jumlah siswa keseluruhan, siswa yang belum lulus sebanyak 11 orang atau sebanyak $52 \%$. Pada siklus ke II dapat terlihat bahwa terdapat peningkatan kemampuan keterampilan passing bawah bola voli, siswa yang lulus sebanyak 19 orang atau sebesar 90,52 \% dan siswa yang tidak lulus sebanyak 2 orang atau sebesar 9,48\%. Dengan demikian dapat disimpulkan bahwa hasil belajar passing bawah terdapat peningkatan pada setiap siklusnya

Untuk lebih jelasnya dapat dilihat pada diagram batang di bawah ini:

Grafik 4.4. Diagram Batang perbandingan hasil Belajar Prasiklus, Siklus I, dan Siklus II

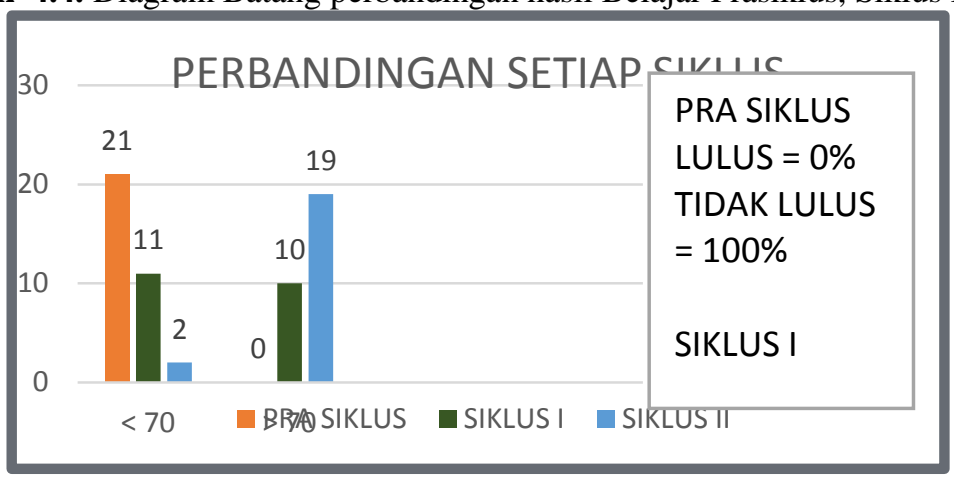

Berdasarlam diagram batang perbandingan hasil belajar passing bawah bola voli pada siswa kelas V SD Negeri Palasari Kota Tasikmalaya tahun ajaran 2015/2015 dapat disimpulkan bahwa terdapat peningkatan hasil belajar passing bawah bola voli pada siswa dari siklus ke siklus.

Melihat dari perbandingan setiap siklus dapat disimpulkan bahwa pembelajaran menggunakan bola modifikasi dapat meningkatkan hasil belajar siswa kelas V SD Negeri Palasari Kota Tasikmalaya tahun ajaran 2015/2016.

Dipublikasikan Oleh : 
Peningkatan tersebut tidak semata-mata dipengaruhi oleh bola modifikasi. Namun, peningkatan hasil belajar dalam setiap pembelajaran juga dipengaruhi oleh guru dan teknik pembelajaran yang digunakan dalam pembelajaran. Teknik pembelajaran yang digunakan dalam penelitian ini adalah permainan. Dengan menerapkan permainan-permainan yang mendukung peningkatan kemampuan mempraktikkan passing bawah bola voli, motivasi siswa bisa meningkat dan berakibat pada aktivitas belajar siswa lebih meningkat.

Selain itu, alat yang digunakan dalam pembelajaran (bola modifikasi) membantu siswa lebih mudah mempelajari teknik dasar passing bawah bola voli karena rasa takut sakit karena perkenaan bola berkurang serta rasa percaya diri yang meningkat. Bola modifikasi ini juga dapat memberikan masukan kepada guru sebagai alternatif dalam memilih media pembelajaran khususnya pembelajaran passing bawah bola voli. Kegiatan dalam pembelajaran yang dilakukan dalam penelitian ini juga dapat menjadi masukan kepada guru untuk mengelola satu pembelajaran yang di desain secara menyenangkan dan membuat anak lebih termotivasi untuk belajar.

Dalam penyampaian materi pembelajaran dikemas dalam desain permainan yang mengandung gerakan dari materi yang diajarkan sehingga membuat siswa dapat berperan aktif selama mengikuti proses pembelajaran dan tujuan pembelajaran dapat tercapai secara maksimal.

\section{KESIMPULAN}

Pembelajaran dengan menggunakan bola modifikasi dan desain pembelajaran yang dibuat dengan memperhatikan karakteristik siswa dapat meningkatkan hasil belajar passing bawah bola voli pada siswa kelas V SD Negeri Palasari tajun ajaran 2015/2016. Karakteristik siwa kelas V sekolah dasar sedang ada pada masa senang bermain. Dengan memanfaatkan berbagai permainan sebagai teknik pembelajaran, kemampuan siswa kelas V SD Negeri Palasari tajun ajaran 2015/2016 mempraktikkan teknik passing bawah bola voli, sangat meningkat. Siswa terlihat termotivasi mengikuti kegiatan pembelajaran. Siswa terlihat senang dan nyaman. Guru lebih mudah melakukan pengelolaan pembelajaran maupun pengelolaan kelas.

Berdasar pada data yang diperoleh pada pra siklus, sikus I dan siklus II terdapat peningkatan di setiap siklusnya. Pada Pra Siklus tidak ada siswa yang mencapai nilai KKM, atau dapat diartikan tidak ada siswa yang lulus. Pada siklus ke I siswa yang lulus sebanyak 10 orang atau sebesar $48 \%$ dan pada siklus ke II naik menjadi 90,48\%. Hal ini menunjukkan bahwa pembelajaran dengan menggunakan bola modifikasi dan desain pembelajaran yang menarik dapat meningkatkan keterampilan passing bawah bola voli pada siswa kelas V SD Negeri Palasari Kota Tasikmalaya. Artinya, pendekatan bola modifikasi dapat meningkatkan hasil belajar passing bawah bolavoli pada siswa kelas V SD Negeri Palasari Kota Tasikmalaya tahun ajaran 2015/2016.

\section{Saran}

Penelitian ini memberikan gambaran secara jelas bahwa menggunakan bola modifikasi dan penerapan desain pembelajaran yang menyenangkan dapat meningkatkan hasil belajar passing bawah bola voli. Hasil penelitian ini dapat digunakan sebagai acuan bagi pengajar dalam merencanakan dan melaksanakan pembelajaran pendidikan jasmani. Pendekatan modifikasi bola dapat digunakan sebagai salah satu alternatif pilihan dalam memilih dan menentukan pendekatan, metode, teknik pembelajaran dan desain instruksionalnya serta dalam memilih media yang tepat dalam pembelajaran pendidikan jasmani, khususnya teknik dasar dalam permainan bola voli.

Desain kegiatan pembelajaran yang dikemas dalam permainan dapat membantu meningkatkan motivasi dan semangat belajar siswa dalam proses pembelajaran. Bola yang tidak keras dan empuk menghapus persepsi siswa mengenai pembelajaran bola voli yang akan menimbulkan rasa sakit dan membosankan karena cara mengajar yang dilakukakn guru kurang variatif atau terlalu monoton.

Guru dapat mengembangkan kreatifitasnya untuk membuat desain pembelajaran yang menarik dan media-media yang disesuaikan dengan tujuan pembelajaran, karakteristik siswa, dan karakteristik materi pembelajaran.

Berdasar pada hasil analisis data, penerapan bola modifikasi dapat merangsang aspek motorik siswa, dapat meningkatkan rasa percaya diri siswa sehingga dalam proses pembelajaran 
siswa lebih aktif dan lebih kreatif yang pada akhirnya dapat mengembangkan kebugaran jasmani siswa.

\section{REFERENSI}

Bachtiar, dkk. (2007). Permainan Besar II Bolavoli dan Bola Tangan, Jakarta:Universitas Terbuka

Bahagia Yoyo dan Sufyar Mujianto, (2009). Pasilitas dan Perlengkapan Penjas. (Bandung: Jurusan Pendidikan Olahraga, FKIP UPI Bandung.

Barth, Katrin dan Richard Heuchert. (2007). Learning Volleyball. New York. Mayer \& Mayer Sport

Beutelstahl Dieter. (2013). Belajar Bermain Bola Voli. Bandung: Pionir Jaya.

Castello, Patrick J.M. (2007). Action Research. New York. British Liblary.

Coker Cheryl A. (2004). Motor Learning and Control for Practitioners. New Mexico: Mc Graw Hill.

Dahlan, M. Djawad. (2006) Psikologi Perkembangan Anak \& Remaja. Bandung. PT. Remaja Rosdakarya.

Danim, Sudarwan. (2010). Perkembangan Peserta didik. Bandung. Alfabeta.

Edwards, William. (2010) Motor Learning and Control From Theory to Practice. California State University. Wadsworth.

Elliott, John. 2001Action Research for Educational Change. Philadephia. Open University Press.

Hopkins, David. (2008)A Teacher's Guide to Classroom Research. New York: McGrawHill.

Huda, Miftahul. (2014)Model-model Pengajaran dan Pembelajaran. Yogyakarta: Pustaka Pelajar.

Husdarta dan Nurlan Kusmaedi. (2010). Pertumbuhan dan Perkembangan, Olahraga dan Kesehatan. Bandung. Alfabeta.

Joyce, Bruce., Marcha weil, dan Emily Calhoun (2009). Models of Teaching (Terjemahan). Yogyakarta: Pustaka Pelajar.

Kemmis, Stephen., Robin McTaggart dan Rhonda Nixon. (2014). The Action Research Planner Doing Critical Participatory Action Research. Singapore: Springer.

Kenny, Bonnie. (2006) Volleyball Step to Success. United States: Human Kinetics.

Lanberg, Kinda S. (2006). Volleyball Skill \& Drill American Volleyball Coaches Association. United States. Human Kinetics.

Mertler, Craig A. (2009). Action Research Teacher Researchers in the Classroom. America. SAGE Publication.

Sagor, Richard. (2005). The Action Research Guidebook. California. Crowin Press.

Samsudin. (2014).Media Pembelajaran Pendidikan Jasmani. Jakarta: Litera Prenada Media Group.

Dipublikasikan Oleh :

UPT Publikasi dan Pengelolaan Jurnal

Universitas Islam Kalimantan Muhammad Arsyad Al-Banjari Banjarmasin 
Santrock, John W. (2011). Educational Psychology. New York: McGraw-Hill.

Schmidt Richard A. and Timoty D. Lee. (2011).Motor Control and Learning. Uniterd States of America. Human Kinetics.

Stringer, Ernest T. (2007). Action Research. United States. Sage Publications.

Sukmadinata, Nana Syaodih. (2010). Metode Penelitian Pendidikan. Bandung. PT Remaja Rosdakarya.

Susanto, Ahmad (2013). Teori Belajar dan Pembelajaran di Sekolah Dasar. Jakarta: Kencana.

Syah, Muhibbin. (2013). Psikologi Pendidikan dengan Pendekatan Baru. Bandung: PT Rosda Karya Offset.

Tangkudung, James dan Wahyuningtyas Puspitorini. (2012). Kepelatihan Olahraga. Jakarta: Cerdas Jaya.

Tim Program Pacasarjana. Buku Pedoman Penulisan Tesis dan Disertasi. Jakarta: PPs UNJ 2012.

Viera, Barbara L. dan Bonnie Jill Ferguson, (1996). Volleyball Tep to Success. Canada: Human Kinetics. 